\title{
PEMBELAJARAN STRUKTUR DAN KEBAHASAAN TEKS EKSPOSISI PESERTA DIDIK KELAS X MIPA-1 SMA NEGERI 7 BANJARMASIN
}

\author{
STRUCTURE AND LINGUISTIC TEXT EXPOSITION LEARNING OF STUDENT \\ CLASS X MIPA-1 SMA NEGERI 7 BANJARMASIN
}

\author{
Annisa Nurshifariani Ahya; Sabhan; Faradina \\ Program Studi Pendidikan Bahasa dan Sastra Indonesia \\ FKIP Universitas Lambung Mangkurat \\ annisanurshifa09@gmail.com
}

\begin{abstract}
Abstrak
Penelitian ini memiliki tujuan untuk mengetahui perencanaan, pelaksanaan, penilaian, kendala, dan upaya dalam pembelajaran struktur dan kebahasaan teks eksposisi di kelas X MIPA-1 SMA Negeri 7 Banjarmasin. Jenis penelitian ini yaitu penelitian deskriptif kualitatif. Pengumpulan data dilakukan dengan cara observasi, wawancara, dan dokumentasi. Hasil penelitian dapat ditarik lima kesimpulan. Pertama, pendidik menggunakan perencanaan pembelajaran yang bersumber dari silabus dan RPP berdasarkan kurikulum 2013. Kedua, pelaksanaan pembelajaran sudah mencakup tahap-tahap $5 \mathrm{M}$ (mengamati, menanya, mencoba, menalar, dan mengkomunikasikan) dalam satu pertemuan dan pada proses pelaksanaan juga terdiri atas tiga kegiatan, yaitu pendahuluan, inti, dan penutup. Ketiga, penilaian autentik dilakukan pendidik untuk menilai sikap, pengetahuan, dan keterampilan. Keempat, kendala pada pembelajaran struktur dan kebahasaan teks eksposisi dibagi menjadi dua, kendala pendidik dan peserta didik. Kelima, upaya untuk mengatasi kendala juga dilakukan oleh pendidik dan peserta didik.
\end{abstract}

Kata kunci: pembelajaran, struktur, kebahasaan, teks eksposisi

\begin{abstract}
This study aims to determine the planning, implementation, assessment, constraints, and efforts in learning the structure and language of the exposition text in class X MIPA-1 SMA Negeri 7 Banjarmasin. This type of research is a qualitative descriptive study. Data collection was carried out by means of observation, interviews, and documentation. The research results can be drawn five conclusions. First, educators use learning planning that comes from the syllabus and lesson plans based on the 2013 curriculum. Second, the implementation of learning includes the 5 M stages (observing, asking, trying, reasoning, and communicating) in one meeting and the implementation process also consists of three activities, namely introduction, core, and closing. Third, authentic assessments are carried out by educators to assess attitudes, knowledge and skills. Fourth, the constraints on learning the structure and language of the exposition text are divided into two, the constraints of educators and students. Fifth, efforts to overcome obstacles are also carried out by educators and students.
\end{abstract}

Keywords: learning, structure, language, exposition text 


\section{Pendahuluan}

Pembelajaran adalah suatu kegiatan yang dilakukan pendidik dan peserta didik untuk mengorganisasi atau mengatur lingkungan fisik maupun nonfisik sehingga dapat digunakan untuk kegiatan proses belajar guna terciptanya tujuan pembelajaran.

Sagala (2010: 62), berpendapat bahwa pembelajaran merupakan proses komunikasi dua arah, mengajar dilakukan oleh pihak guru sebagai pendidik, sedangkan belajar dilakukan oleh pihak peserta.

Peneliti berpandapat bahwa keterampilan peserta didik untuk menulis masih terbatas. Tidak dapat mengembangkan gagasan atau ide dalam karangan adalah contoh permasalahan yang terjadi pada peserta didik karena kurangnya informasi yang menyebabkan peserta didik kesulitan untuk mengolah ide menjadi sebuah karangan. Kesulitan-kesulitan ini akan berdampak pada kemampuan yang dimiliki. Apabila kemampuan mereka dalam menulis teks masih rendah, KD 4.3 yaitu menganalisis struktur dan kebahasaan teks eksposisi, tidak tercapai dengan maksimal. Oleh karena itu, peneliti ingin meneliti Pembelajaran Struktur dan Kebahasaan Teks Eksposisi Peserta Didik Kelas X MIPA-1 SMA Negeri 7 Banjarmasin.
Penelitian ini membahas pembelajaran teks eksposisi yang berfokus pada struktur dan kebahasaannya. Pengertian teks eksposisi adalah teks yang dibangun oleh pendapat atau opini penulis. Eksposisi biasanya digunakan penulis untuk menyajikan gagasan. Gagasan tersebut dikaji oleh penulis berdasarkan sudut pandang tertentu dengan menyertakan alasan-alasan yang logis.

Tujuan penelitian ini adalah untuk mendeskripsikan perencanaan, pelaksanaan, dan penilaian dalam proses pembelajaran. Alasan peneliti mengambil judul ini karena masih banyak hal yang harus diperbaiki dalam menulis teks eksposisi dengan model pembelajaran yang tepat demi tercapainya indikator menulis teks eksposisi yang memfokuskan pada struktur dan kebahasaannya.

Selain berdasarkan pengamatan tersebut, peneliti ingin meneliti Pembelajaran Struktur dan Kebahasaan Teks Eksposisi Peserta Didik Kelas X MIPA-1 SMA Negeri 7 Banjarmasin karena melihat artikel jurnal penelitian terdahulu yaitu oleh Fitriyani, dkk (2014) tentang Pembelajaran Struktur Teks Eksposisi Pada Siswa Kelas VII SMPN 1 Bandarlampung. Penelitian ini meneliti tentang struktur teks eksposisi pada jenjang SMP. Oleh karena itu, peneliti tertarik melanjutkan penelitian tersebut dengan 
data yang ditambah unsur kebahasaan teks ekposisi pada jenjang SMA agar dapat diteliti secara keseluruhan.

\section{Metode Penelitian}

\section{Jenis Penelitian}

Deskriptif kualitatif digunakan peneliti sebagai jenis penelitian.

\section{Waktu dan Tempat Penelitian}

Waktu penelitian dilakukan pada Kamis, 14 November 2019 pukul 11.00 s.d. 12.30 WITA. Tempat penelitian ini yaitu di $\begin{array}{lllll}\text { kelas } & \mathrm{X} & \text { MIPA-1 } & \text { SMA Negeri } 7\end{array}$ Banjarmasin tahun pelajaran 2019-2020.

\section{Target atau Subjek Penelitian}

Peserta didik kelas X MIPA-1 SMA Negeri 7 Banjarmasin yang berjumlah 40 orang merupakan subjek dalam penelitian ini.

\section{Prosedur}

Prosedur penelitian ini yaitu data deskriptif kualitatif dan terdiri atas beberapa tahap. Pertama, melakukan observasi untuk mengetahui pembelajaran struktur dan kebahasaan teks eksposisi peserta didik. Kedua, target penelitian yaitu peserta didik kelas X MIPA-1 SMAN 7 Banjarmasin yang berjumlah 40 orang. Ketiga, setelah menentukan target penelitian, peneliti mengambil data pendidik dan peserta didik dalam bentuk video pembelajaran dan dokumen RPP. Keempat, menganalisis data yang sudah terkumpul berdasarkan beberapa tahapan. Tahapan tersebut yaitu reduksi data, penyajian data, dan penarikan simpulan. Kelima, penyajian data. Keenam, penarikan simpulan dari hasil analisis data.

\section{Data, Instrumen, dan Teknik Pengumpulan Data}

Data dalam penelitian ini yaitu proses pembelajaran yang terdiri atas aktivitas pendidik dan peserta didik yang diamati melalui observasi. Penelitian ini menggunakan instrumen penelitian yaitu peneliti sendiri atau human instrument. Kemudian, teknik observasi, wawancara, dan dokumentasi adalah teknik pengumpulan data dalam penelitian ini.

\section{Teknik Analisis Data}

Analisis data melalui empat tahap, pertama pengumpulan data, kedua reduksi data, ketiga penyajian data, dan keempat verifikasi data. Pertama, pengumpulan data hasil observasi, wawancara, dan dokumentasi merupakan analisis data. Kedua, reduksi data, ialah merangkum atau menyederhanakan data yang dilakukan melalui seleksi. Ketiga, penyajian data yaitu mendeskripsikan hasil temuan selama pengamatan, wawancara, dan dokumen sebagai penunjang data. Keempat, verifikasi data yaitu menjawab rumusan masalah. dengan membuat kesimpulan.

\section{Hasil Penelitian dan Pembahasan}

(1) Perencanaan pembelajaran, (2) proses pembelajaran, (3) penilaian pembelajaran, (4) kendala pendidik dan peserta didik, dan (5) upaya pendidik 
mengatasi kendala pembelajaran

merupakan hasil dan pembahasaan

penelitian ini.

\section{Perencanaan Pembelajaran}

Pendidik di kelas menggunakan perencanaan pembelajaran, yaitu RPP kurikulum 2013 dan silabus. Pada penelitian ini, peneliti menganalisis, menafsirkan, dan menilai perencanaan pembelajaran yang merujuk pada RPP yang digunakan pendidik untuk empat kali pertemuan, tetapi untuk penelitian ini peneliti hanya meneliti pada pertemuan ketiga yaitu KD 3.4 yang membahas tentang struktur dan kebahasaan teks eksposisi. Indikator, tujuan, materi, metode, media/alat pembelajaran, sumber belajar, langkah-langkah pembelajaran, dan penilaian pembelajaran merupakan bagian yang dianalisis oleh peneliti.

Indikator yang tercantum pada RPP teks eksposisi SMA Negeri 7 Banjarmasin berdasarkan peneliti telah memenuhi kriteria utama dalam perumusan indikator. Akan tetapi, ada beberapa perbedaan antara RPP dengan pelaksanaan pembelajaran yang dilakukan pendidik. Indikator yang kurang tercapai pada pertemuan kali ini dikarenakan pendidik lebih fokus pada materi yang sudah diajarkan sebelumnya, yaitu tentang jenis teks eksposisi padahal materi pertemuan kali ini adalah mengenai struktur dan kebahasaan. Seharusnya pendidik lebih menjelaskan struktur dan kebahasaan lebih detail disertai dengan contoh konkret sehingga peserta didik bisa memahami materi dan indikator pembelajaran juga tercapai dengan baik.

Tujuan pembelajaran di RPP sudah sesuai dengan perumusan tujuan yang benar, adanya kata kerja operasional sudah dijabarkan pada aspek sikap, pengetahuan, dan keterampilan. Akan tetapi, pendidik tidak menyampaikan tujuan pembelajaran yang seharusnya disampaikan sebelum memulai pembelajaran.

Materi pembelajaran yang tertulis di RPP sudah benar dan sesuai dengan rumusan materi pembelajaran di RPP kurikulum 2013. Akan tetapi, ada materi yang tidak dijelaskan secara mendalam, padahal seharusnya materi itu harus dijelaskan karena sudah tertulis di indikator dan konsep materi pembelajaran sehingga peserta didik kurang memahami kebahasaan teks eksposisi, pendidik hanya terfokus mengajarkan jenis dan struktur teks eksposisi.

Metode yang tertulis di RPP dan pelaksanaannya di kelas terdapat perbedaan, yaitu pada saat di kelas pendidik tidak memberikan tugas diganti dengan tanya jawab. Alasan pendidik tidak memberikan tugas karena tugas diberikan pada saat pertemuan selanjutnya, pada pertemuan kali ini pendidik hanya menjelaskan materi jenis dan struktur teks eksposisi dengan metode ceramah, diskusi, dan tanya jawab. 
Sedangkan untuk pendekatan dan model pembelajaran yang tertulis di RPP sudah sesuai dan diterapkan pada pelaksanaan di kelas.

Ada beberapa media yang sudah tertulis di RPP tidak digunakan pendidik pada saat pelaksanaan di kelas, pendidik menggunakan lembar penilaian guru dan lembar kerja peserta didik pada saat pertemuan selanjutnya.

Sumber belajar yang tertulis di RPP hanya buku LKS saja yang digunakan, buku paket tidak digunakan oleh pendidik. Alangkah baiknya pendidik menggunakan dua buku yang sudah tertulis di RPP untuk menambah referensi peserta didik untuk memahami teks eksposisi.

Ada langkah-langkah yang tidak dilaksanakan pendidik. Beberapa langkahlangkah tidak sesuai dengan RPP, tetapi secara garis besarnya tidak keluar pada pendekatan, model dan metode yang ditulis sesuai RPP. Langkah-langkah yang tidak dilaksankan oleh pendidik diantaranya tidak melakukan apersepsi, pemberian acuan, kegiatan literasi, dan mempresentasikan hasil kerja peserta didik.

Pendidik menggunakan penilaian autentik kurikulum 2013 yang sudah sesuai dengan RPP. Penilaian autentik mencakup tiga ranah, yaitu penilaian sikap, penilaian pengetahuan, dan penilaian keterampilan. Penilaian jurnal dilakukan oleh pendidik untuk menilai kompetensi sikap. Penilaian pengetahuan dinilai melalui tes tulis dengan instrumen tes tulis berupa soal esai sebanyak empat soal dan kompetensi keterampilan dinilai pendidik melalui proses membuat teks eksposisi dengan memperhatikan struktur dan kebahasannya.

\section{Proses Pembelajaran}

Berdasarkan hasil penelitian, berperan aktif dalam pembelajaran di kelas harus dilakukan oleh peserta didik. Pendidik harus merancang dan mempertimbangkan situasi dan kondisi terjadinya proses belajar. Pada saat di kelas pendidik harus mengontrol jalannya proses pembelajaran sehingga proses pembelajaran berjalan dengan lancar. Pelaksanaan pembelajaran meliputi pendahuluan, kegiatan inti, dan penutup. Materi, media, metode, dan evaluasi merupakan unsur-unsur yang membangun proses pelaksanaan pembelajaran struktur dan kebahasaan teks eksposisi. Pada pelaksanaan pembelajaran pendidik menggunakan pendekatan ilmiah atau saintifik pada kegiatan inti sesuai dengan kurikulum 2013. Berikut pelaksanaan pembelajaran struktur dan kebahasaan pada materi teks eksposisi dari pendahuluan, kegiatan inti, dan penutup.

\section{Pendahuluan}

Berdasarkan hasil penelitian, pendidik hanya melaksanakan kegiatan pendahuluan dengan mengucapkan salam dilanjutkan dengan berdoa bersama, yang dipimpin 
oleh ketua kelas, setelah itu melakukan presensi dan ada satu perserta didik tidak hadir dengan alasan sakit. Pendidik tidak melakukan penyiapan peserta didik secara fisik dan psikis, tidak memberikan motivasi belajar, tidak memberikan pertanyaan yang mengaitkan materi sebelumnya dengan materi yang akan dipelajari, tidak menyampaikan tujuan dan kompetensi dasar, dan tidak menyampaikan uraian kegiatan merupakan kegiatan pendahuluan yang tidak dilakukan pendidik. Pendidik langsung pada kegiatan inti dengan menjelaskan materi pembelajaran.

\section{Kegiatan Inti}

Pada kegiatan inti, pendidik melaksanakan proses pembelajaran dengan pendekatan ilmiah atau saintifik Pembelajaran melibatkan lima keterampilan proses, yaitu mengamati, menanya, mencoba, menalar, dan mengkomunikasikan merupakan penerapan pendekatan ilmiah. Kelima tahapan tersebut disingkat dalam $5 \mathrm{M}$. Pada pelaksanaan kegiatan $5 \mathrm{M}$ di kelas tidak selalu terjadi secara berurutan, ada yang terulang dan hanya dilakukan satu kali. Akan tetapi, semua kegiatan berjalan dengan baik dan lancar dalam satu kali pertemuan.

\section{Kegiatan Penutup}

Pada kegiatan penutup pendidik hanya melakukan kegiatan membuat rangkuman atau simpulan bersama peserta didik dan memberikan kesempatan mereka untuk bertanya. Kegiatan penilaian secara konsisten dan terprogram tidak dilakukan pendidik pada pertemuan hari itu karena tidak adanya pemberian tugas individu atau kelompok, pendidik melakukan penilaian dengan menilai hasil kerja peserta didik pada pertemuan berikutnya. Pendidik tidak menyampaikan materi pertemuan atau rencana pembelajaran pada pertemuan berikutnya. Kegiatan penutup ditutup setelah pendidik bersama peserta didik melakukan kesimpulan materi dan memberikan kesempatan bertanya kepada peserta didik, selanjutnya diakhiri dengan mengucapkan salam.

\section{Penilaian Pembelajaran}

Pada penilaian pengetahuan, pendidik menilai dari hasil tes tertulis individu dengan menjawab soal esai di lembar RPP sebanyak empat soal. Di bawah ini hasil penilaian pengetahuan pendidik.

Tabel Nilai Peserta Didik Materi Teks

Eksposisi

\begin{tabular}{|l|l|l|l|}
\hline No & Nama & $\begin{array}{l}\text { KD } \\
3.4\end{array}$ & Keterangan \\
\hline 1. & $\begin{array}{l}\text { Alfath Javier } \\
\text { Arya Putra }\end{array}$ & 60 & Kurang \\
\hline 2. & $\begin{array}{l}\text { Aditya Fadhil } \\
\text { Nugraha }\end{array}$ & 90 & Amat baik \\
\hline 3. & Adi Raihan & 85 & Baik \\
\hline 4. & $\begin{array}{l}\text { Angelina } \\
\text { Ivanna Genardi }\end{array}$ & 90 & Amat baik \\
\hline 5. & $\begin{array}{l}\text { Akram Arifah } \\
\text { Pagis }\end{array}$ & 93 & Amat baik \\
\hline
\end{tabular}




\begin{tabular}{|c|c|c|c|}
\hline 6. & $\begin{array}{ll}\text { Carin } & \text { Fiona } \\
\text { Huang } & \\
\end{array}$ & 87 & Baik \\
\hline 7. & Davi Hendra & 70 & Cukup \\
\hline 8. & $\begin{array}{ll}\text { Della } & \text { Fasya } \\
\text { Azzahra } & \end{array}$ & 65 & Kurang \\
\hline 9. & Daffa Arief & 100 & Amat baik \\
\hline 10. & $\begin{array}{l}\text { Helda } \\
\text { Rahmawati }\end{array}$ & 95 & Amat baik \\
\hline 11. & $\begin{array}{l}\text { Helena Audrey } \\
\text { Tjhie }\end{array}$ & 95 & Amat baik \\
\hline 12. & $\begin{array}{l}\text { Helyudi } \\
\text { Ananda Noor }\end{array}$ & 85 & Baik \\
\hline 13. & Ihya Musliana & 95 & Amat baik \\
\hline 14. & $\begin{array}{ll}\text { Ikmal } & \text { Aris } \\
\text { Farendra } & \end{array}$ & 90 & Amat baik \\
\hline 15. & $\begin{array}{ll}\text { M. } & \text { Syabit } \\
\text { Ikhsan } & \end{array}$ & 70 & Cukup \\
\hline 16. & M. Kamal Zain & 95 & Amat baik \\
\hline 17. & $\begin{array}{l}\text { Meilinda } \\
\text { Dwiyanti M. }\end{array}$ & 80 & Baik \\
\hline 18. & M. Abel Putra & 80 & Baik \\
\hline 19. & $\begin{array}{l}\text { M. Adrian Dwi } \\
\text { Putra }\end{array}$ & 87 & Baik \\
\hline 20 & M.Ali Wafa & 97 & Amat baik \\
\hline 21 & $\begin{array}{ll}\text { M. } & \text { Asrya } \\
\text { Dimas } & \\
\end{array}$ & 100 & Amat baik \\
\hline 22. & M. Ihsan & 90 & Amat baik \\
\hline 23. & M. Indra Jati & 97 & Amat baik \\
\hline 24. & M. Irfan & 65 & Kurang \\
\hline 25 & $\begin{array}{ll}\text { M. Noufal } \\
\text { Ikhsan }\end{array}$ & 97 & Amat baik \\
\hline 26. & $\begin{array}{l}\text { M. Rifky } \\
\text { Priyamba }\end{array}$ & 97 & Amat baik \\
\hline 27 & $\begin{array}{l}\text { M. Revano } \\
\text { Maswandi }\end{array}$ & 90 & Amat baik \\
\hline 28. & M. Rizqon T. & 100 & Amat baik \\
\hline 29. & $\begin{array}{l}\text { Mulia Helmi } \\
\text { Hendriyanto }\end{array}$ & 95 & Amat baik \\
\hline 30. & Nabila Azahra & 95 & Amat baik \\
\hline 31. & Nai'mah & 90 & Amat baik \\
\hline 32. & $\begin{array}{l}\text { Nayla Nafirda } \\
\text { Azizah }\end{array}$ & 95 & Amat baik \\
\hline 33. & $\begin{array}{l}\text { Nida } \\
\text { Hasanah }\end{array}$ & 90 & Amat Baik \\
\hline 34. & $\begin{array}{l}\text { Puan Shofiya } \\
\text { Mubarika }\end{array}$ & 90 & Amat baik \\
\hline 35. & Radit Alfard & 88 & Baik \\
\hline
\end{tabular}

\begin{tabular}{|c|l|l|l|}
\hline 36. & $\begin{array}{l}\text { Raffi Anugrah } \\
\text { Tyaga }\end{array}$ & 68 & $\begin{array}{l}\text { Kurang } \\
\text { Baik }\end{array}$ \\
\hline 37. & Rifa Nur Afifah & 100 & Amat baik \\
\hline 38. & Raisa Hafizah & 90 & Amat baik \\
\hline 39. & $\begin{array}{l}\text { Sugiharto } \\
\text { Wicaksono W. }\end{array}$ & 80 & Baik \\
\hline 40. & William Nata & 60 & $\begin{array}{l}\text { Kurang } \\
\text { baik }\end{array}$ \\
\hline
\end{tabular}

\section{Keterangan:}

Nilai KKM: > 70

Hitam: Nilai di atas KKM

Merah: Nilai di bawah KKM

Dari hasil penilaian pendidik kepada peserta didik, dapat disimpulkan bahwa ada beberapa peserta didik yang mendapat nilai dibawah 70 sehingga nilai mereka di bawah KKM. Dari total 40 orang terdapat lima peserta didik yang nilainya di bawah KKM dengan rentang nilai 60-68. Ada dua peserta didik yang nilainya cukup yaitu sesuai dengan KKM. Ada delapan peserta didik yang nilainya baik dengan rentang nilai 70-80 dan sisanya ada 25 peserta didik yang nilainya amat baik dengan rentang nilai 90-100.

Penilaian pada tabel di atas didapat peserta didik dari hasil tes tertulis berbentuk esai sebanyak empat soal di RPP yang dibuat pendidik. Perbedaan nilai di atas karena pada saat mengerjakan tugas menentukan struktur dan kebahasaan teks eksposisi rata-rata kesalahannya sama. Peserta didik masih belum memahami dengan baik materi yang sudah diajarkan terutama materi kebahasaan teks eksposisi karena materi itu kurang diajarkan lebih 
mendalam, pendidik hanya terfokus pada materi jenis dan struktur teks eksposisi saja sehingga banyak peserta didik yang mengalami kesalahan ketika diminta untuk mengalisis kebahasaan teks eksposisi yang mereka cari.

\section{Kendala dalam Proses Pembelajaran}

Kendala yang terjadi pada proses pembelajaran ini diambil berdasarkan data hasil wawancara dengan responden. Penelitian ini menggunakan responden sebanyak tujuh orang, enam orang peserta didik dan satu orang pendidik. Responden peserta didik masing-masing dua orang pada level atas, dua orang pada level tengah, dan dua orang pada level bawah dengan tujuan untuk menjelaskan kendala yang dihadapi peserta didik secara keseluruhan terhadap pembelajaran struktur dan kebahasaan teks eksposisi.

Setelah melakukan wawancara dengan pendidik, dapat disimpulkan bahwa kendala pertama, yaitu perubahan kurikulum yang sering terjadi sehingga berimbas pada proses pembelajaran yang berakibat pemahaman peserta didik yang dirasa kurang. Kedua, diskusi kelompok. Biasanya tidak semua peserta didik berpartisipasi secara aktif dalam diskusi kelompok. Hanya beberapa peserta didik yang mau mengerjakan tugas dari pendidik. Terakhir, kurangnya literasi peserta didik juga menjadi penyebab mereka kesulitan menemukan ide untuk menulis teks eksposisi berdasarkan struktur dan kebahasaannya.

Kendala yang dialami oleh peserta didik dalam belajar teks eksposisi, yaitu pertama peserta didik belum memahami cara pendidik dalam menjelaskan materi teks eksposisi. Pendidik kurang menjelaskan materi sehingga peserta didik merasa kebingungan dengan materi yang diajarka. Kedua, ketika pelaksanaan tugas kelompok ada beberapa peserta didik yang hanya menulis nama tanpa ikut berpartisipasi dalam mengerjakan soal. Hal itu membuat peserta didik yang mengerjakan dengan sungguh-sungguh merasa kesal karena ada temannya yang tidak mengerjakan padahal tugasnya secara berkelompok bukan individu.

Ketiga gaya mengajar pendidik yang monoton, lebih banyak mengajar dengan metode ceramah dan lebih banyak duduk di tempat jarang menjelaskan dengan berdiri. Hal itu berdampak pada kurangnya antusias peserta didik dalam mengikuti pembelajaran. Selain itu, peserta didik juga menganggap pembelajaran berbasis teks dirasa membosankan karena membaca teks yang jumlahnya banyak. Terakhir, kemampuan peserta didik dalam menuangkan ide menjadi sebuah teks masih terbatas dan perlu adanya tindak lanjut dari pendidik untuk mengatasi masalah ini. Terbatasnya pengetahuan yang mereka miliki dan sedikitnya perbendaharaan kata 
yang mereka kuasai mengakibatkan mereka sulit untuk merangkai kata ketika disuruh membuat teks eksposisi. Pendidik lebih fokus pada materi jenis dan struktur teks eksposisi tanpa mengajarkan lebih dalam tentang menulis teks eksposisi.

\section{Upaya Pendidik Mengatasi Kendala Proses Pembelajaran}

Upaya yang dapat dilakukan pendidik untuk mengatasi kendala pada proses pembelajaran struktur dan kebahasaan teks eksposisi. Pertama, pendidik harus menguasai secara mendalam silabus, RPP, dan materi yang sering terjadi perubahan karena adanya perubahan kurikulum yang dilakukan pemerintah. Kedua, pendidik menggunakan buku LKS yang diterbitkan PT Intan Pariwara sebagai sumber materi. Akan tetapi, LKS belum memuat materi dan contoh teks yang lengkap sehingga pendidik harus menggunakan referensi lain seperti internet, artikel, surat kabar, dan lain-lain.

Ketiga, upaya pendidik untuk mengatasi kendala ketika diskusi kelompok yaitu dengan selalu mengawasi dan memberi tugas yang merata kepada peserta didik. Tujuannya agar seluruh anggota kelompok aktif mengerjakan tugas yang diberikan. Keempat, mengatasi kendala media pada pertemuan selanjutnya dengan menampilkan tayangan atau PPT dan membagikan rangkuman materi yang sudah dicetak untuk mempermudah peserta didik memahami materi yang disampaikan dan bisa membaca sera mengulang materi di rumah. Perpustakaan sekolah bisa digunakan pendidik sebagai media untuk mendapatkan informasi tambahan.

Selain mengatasi kendala pada diri pendidik. Pendidik juga harus mengatasi kendala yang dialami peserta didik. Pendidik mengatasi kendala dalam pembelajaran dari segi peserta didik dengan upaya yaitu pertama, pendidik kurang menjelaskan materi bisa diupayakan dengan cara mengajak peserta didik ke perpustakaan. Media perpustakaan sebagai sarana menggali ilmu bisa dioptimalkan oleh pendidik. Kegiatan berkunjung atau proses belajar di perpustakaan bisa menjadi alternatif lain bagi peserta didik untuk membiasakan diri membaca dari berbagai referensi yang ada di perpustakaan. Pengulangan materi merupakan upaya yang bisa dilakukan agar peserta didik lebih paham dan bisa mengulang materi yang telah dipelajari.

Kedua, kendala pada model pembelajaran berkelompok bisa diupayakan dengan cara membagi tugas secara merata kepada setiap anggota kelompok. Apabila ada anggota kelompok yang tidak bekerja maka akan diberi teguran dan untuk kelompok terbaik bisa diberikan apresiasi agar memacu semangat mereka dalam mengerjakan tugas 
kelompok. Ketiga, kendala minat peserta didik bisa diupayakan dengan cara melakukan inovasi dalam hal metode dan model pembelajaran yang menarik agar meningkatkan minat peserta didik terhadap pembelajaran bahasa Indonesia. Pemilihan media dan metode pembelajaran yang efektif harus dilakukan oleh pendidik supaya peserta didik mengikuti pembelajaran secara aktif dan tidak cepat bosan.

Terakhir, kendala kemampuan peserta didik dalam membuat teks eksposisi bisa diupayakan dengan selalu memberikan motivasi kepada peserta didik agar gemar membaca. Meningkatkan kegiatan membaca bisa mengatasi pengetahuan dan perbendaharaan kata yang rendah Selain motivasi gemar membaca, memberikan pengayaan latihan menulis bagi peserta didik juga bisa dilakukan oleh pendidik.

\section{Simpulan dan Saran}

\section{Simpulan}

Setelah melakukan analisis data, dapat ditarik kesimpulan, yaitu: Pertama, perencanaan pembelajaran pendidik dengan menyiapkan silabus dan RPP dengan baik. Pendidik belum menjalankan RPP dengan baik sehingga perencanaan pembelajaran yang telah dilakukan belum sesuai dengan kurikulum 2013. Masih banyak skenario pembelajaran yang belum dilaksanakan pendidik. Akan tetapi, proses pembelajaran berjalan dengan lancar.
Kedua, pelaksanaan pembelajaran struktur dan kebahasaan teks eksposisi yang dilakukan oleh pendidik sudah mencakup tahap-tahap $5 \mathrm{M}$ (mengamati, menanya, mencoba, menalar, dan mengkomunikasikan) dalam satu pertemuan. Tahap-tahapnya juga sesuai urutan walaupun ada pengulangan tahap dalam beberapa kali. Kegiatan pendahuluan, inti, dan penutup merupakan tiga proses pembelajaran. Ketiga, proses pembelajaran ini menggunakan penilaian autentik kurikulum 2013. Penilaian autentik meliputi penilaian sikap, pengetahuan, dan keterampilan. Akan tetapi, pendidik hanya diberikan penilaian pengetahuan kepada peneliti sehingga hanya penilaian pengetahuan yang bisa dianalisis.

Keempat, kendala yang timbul dalam struktur dan kebahasaan teks eksposisi dikelompokkan menjadi kendala pendidik dan kendala peserta didik. Kendala pendidik meliputi; perubahan kurikulum, materi bahan ajar, metode pembelajaran, dan media pembelajaran. Sedangkan kendala yang dialami peserta didik meliputi; pendidik kurang menjelaskan materi, model pembelajaran khususnya secara berkelompok, minat peserta didik, dan kemampuan menulis teks eksposisi.Terakhir, upaya untuk mengatasi kendala dalam pembelajaran struktur dan kebahasaan teks eksposisi sebagai berikut; 
Kendala pendidik diatasi dengan: (1) pendidik harus menguasai secara mendalam silabus, RPP, dan materi; (2) pendidik bisa mencari sumber referensi lain untuk menyampaikan materi sesuai dengan kondisi peserta didik; (3) ketika diskusi kelompok berlangsung pendidik memberikan tugas kepada peserta didik secara adil dan merata; (4) pendidik lebih sering menggunakan tayangan video, PPT dan salinan materi yang dicetak. Sedangkan kendala yang dialami peserta didik, disiasati pendidik sebagai berikut: (1) mengatasi pendidik kurang menjelaskan materi bisa diupayakan dengan cara mengajak peserta didik ke perpustakaan; (2) pendidik memberi tugas kelompok secara merata kepada peserta didik agar semua bisa mengerjakan; (3) melakukan inovasi dalam hal metode dan model pembelajaran yang menarik; meningkatkan motivasi mereka untuk gemar membaca agar bisa membuat teks eksposisi.

\section{Saran}

\section{Untuk Pendidik}

Pendidik diharapkan lebih meningkatkan proses dan mutu pembelajaran agar menarik. Materi yang diberikan harus dari berbagai sumber referensi sehingga pengetahuan peserta didik semakin luas. Media yang dipilih sebaiknya menyesuaikan dengan kondisi peserta didik. Selanjutnya, metode pembelajaran yang tepat juga memengaruhi kualitas pembelajaran sehingga tujuan pembelajaran yang diinginkan tercapai.

\section{Untuk Peserta Didik}

Peserta didik diharapkan lebih menghargai pendidik dan berani menyampaikan pernyataan atau masalah yang belum dipahami. Selain itu, peserta didik diharapkan mengasah kemampuan menulis teks eksposisi dengan membiasakan kegiatan membaca agar bisa menulis teks eksposisi dengan benar.

\section{Untuk Pihak Sekolah}

Pihak sekolah diharapkan dapat menambah dan memperbaharui buku bacaan yang sesuai dengan materi pelajaran bahasa Indonesia yang dapat menunjang proses pembelajaran di kelas. Selain itu, sekolah harus memerhatikan perawatan fasilitas yang sudah ada dan kinerja pendidik juga harus selalu diperhatikan dan dievaluasi agar kualitas pembelajaran tidak menurun.

\section{Daftar Pustaka}

\section{a. Dari Buku Teks}

Arsyad, A. 2013. Media Pembelajaran. Jakarta: PT Raja Grafindo Persada.

Darmawati, Uti dan Budi Artati, Y. 2019.

Bahasa Indonesia untuk SMA/MA Kelas X Semester 1. Klaten: PT Intan Pariwara.

Darmawati, Uti. 2014. Ensiklopedia Bahasa dan Sastra Indonesia. Ragam Teks. Klaten: PT Intan Pariwara.

Djatmiko. 2018. Mengenal Teks dan Cara Pembelajarannya. Yogyakarta: Pustaka Pelajar. 
Fadlillah, M. 2014. Implementasi Kurikulum 2013 dalam Pembelajaran SD/MI, SMP/MTS/ \& SMA/MA. Yogyakarta: Ar-Ruzz Media.

Ghony, M. Djunaidi dan Almansur, Fauzan. 2016. Metode Penelitian Kualiatif. Yogyakarta: Ar-Ruzz Media.

Hamalik, Oemar. 1995. Kurikulum dan Pembelajaran. Jakarta: Bumi Aksara.

Haris. 2008. Evaluasi Pembelajaran. Yogyakarta: Multi Presindo.

Kokasih. Kurniawan, Endang. 2019. JenisJenis Teks (Fungsi, Struktur, dan Kaidah Kebahasaan). Bandung: Yrama Widya.

Kurniawan, Asep. 2018. Metodologi Penelitian Pendidikan. Bandung: PT Remaja Rosdakarya.Mahsun. 2014. Teks dalam Pembelajaran Bahasa Indonesia Kurikulum 2013. Jakarta: Rajawali Press.

Margono, S. 2003. Metodologi Penelitian Pendidikan. Jakarta: PT Rineka Cipta.

Marwiyah, St. Alauddin., dan Muh. Khaerul Ummah BK. 2018. Perencanaan Pembelajaran Kontemporer Berbasis Penerapan Kurikulum 2013. Yogyakarta: Deepublish.

Moleong, Lexy J. 2018. Metodologi Penelitian Kualitatif. Bandung: PT. Remaja Rosdakarya.

Mulyasa. E. 2003. Kurikulum Berbasis Kompetensi:

Konsep,Karakteristik dan Implementasi. Bandung: PT Remaja Rosda Karya.

Musaba, Zulkifli. 2018. Dasar-Dasar Keterampilan Menulis. Yogjakarta: Aswaja Pressindo.

Prastowo, Andi. 2014. Memahami MetodeMetode Penelitian: Suatu Tinjauan Teoritis dan Praktis. Jogjakarta: Ar-Ruzz Media.

Priyatni, Endah Tri. 2014. Desain Pembelajaran Bahasa Indonesia dalam Kurikulum 2013. Jakarta: PT Bumi Aksara.

Purwati, Loeloek Endah dan Sofan Amri. 2013. Paduan Memahami Kurikulum 2013. Jakarta: PT. Prestasi Pustakarya.

Sagala, Syaiful. 2010. Konsep dan Makna Pembelajaran. Bandung: Alfabeta.

Sugiyono. 2013. Metode Penelitian Kuantitatif, Kualitatif, dan $R \& D$. Bandung: Alfabeta.

Suparno.2011. Keterampilan Dasar Menulis. Jakarta: Universitas Terbuka.

\section{b. Dari skripsi/tesis/desertasi}

Oktavia, Triya. 2015. Peningkatan Keterampilan Menulis Teks Eksposisi Melalui Model Investigasi Kelompok pada Siswa Kelas X-4 TKJ SMK NU Ungaran Kabupaten Semarang Tahun Pelajaran 2014/2015. Semarang. Universitas Negeri Semarang. Skripsi.

Widoyoko, Ghani. 2015. Pelaksanaan Pembelajaran Teks Eksposisi Berdasar Kurikulum 2013 Pada Siswa Kelas VII SMP N 3 Tempuran Magelang. Yogjakarta. Universitas Negeri Yogjakarta. Skripsi.

\section{c. Dari Jurnal}

Fitriani, Fuad, dan Suyanto. 2013. Pembelajaran Struktur Teks Eksposisi Pada Siswa Kelas VII SMPN 1 Bandar Lampung. Jurnal Kata (Bahasa, Sastra, dan Pembelajarannya).

Hesti, Kundharu, Dan Chafit. 2015. Implementasi Kurikulum 2013 Pada Pembelajaran Menulis Teks Eksposisi (Studi Kasus Di Kelas X SMK Negeri 1 Karanganyar). Basastra Jurnal Penelitian Bahasa, Sastra Indonesia dan Pengajarannya. Volume 3 Nomor 3. 